\title{
ON THE GRAMMATICALIZATION OF THE ESTONIAN PERFECTIVE PARTICLES*
}

\author{
ANNE TAMM
}

\begin{abstract}
This article presents two grammaticalization types of separable perfective particles in Estonian. The bounding particle (BP) use of the semantically most bleached Estonian separable verbal particle $\ddot{a r a}$ is demonstrated to display a distinct status in the grammaticalization of aspect. The special character of the BP is illustrated by contrasting the BP $\ddot{a} r a$, on the one hand, with the well-established use of the particle with the same form (ära) and, on the other hand, several other perfective particles, which are referred to here as instances of completive particles (CP). The study of differences brings out the following novel facts about the BP. The particle occurs only in contextdependent, agentive sentences that typically describe the achievement of planned or foreseen endpoints of events. The perfective sentences with the BP contain primarily activity verbs; however, verbs in such sentences can belong to all aspectual classes, and the combinations are transparent. The occurrence of an argument that would serve as a "measure" for the event is thereby optional. The evidence that the BP and verb combinations do not allow for the derivation of adjectives (participles) also demonstrates the difference between the principles of combining a verb and a BP as opposed to a CP.
\end{abstract}

\section{Introduction}

The topic of this paper is the grammaticalization of Estonian aspect. I will show that changes are taking place in the use of what are traditionally called perfective particles in Estonian. More specifically, I will draw the reader's attention to the emergence of what is termed here the bounding particle. I will present evidence that some uses of the particle $\ddot{a r a}$, illustrated in example (1), are significantly different from the wellestablished uses of the same perfective particle (presented in section 3.1) and other perfective particles.

* I am grateful to the audience of the Uralic Workshop in Budapest and the anonymous reviewers. I am grateful to András Komlósy, Helle Metslang, Chris Piñón, and Gabriella Tóth for commenting on several earlier versions of the paper and Chris Piñón for discussing the particle ära before my presenting the paper at the workshop. Mistakes are my responsibility.

1216-8076/\$20.00 (c) 2004 Akadémiai Kiadó, Budapest 
(1) Mind kutsuti reklaamipäevale klouni mängima. I.part invite.impers.past advertising_day.all clown.part play.ma-inf Mängisin klouni ära ja sain kada krooni. play.1sg.past clown.gen ptcl and get.1sg.past a hundred.nom kroon.part 'I was invited to play a clown on the advertising day. So I played the clown and got 100 kroons.'

(Reporting data on colloquial usage, Metslang 2001) ${ }^{1}$

This use of the semantically most bleached separable verbal particle $\ddot{a} r a$ has the following characteristics:

1 it occurs typically in embedded, agentive contexts describing planned or foreseen events; it occurs only in sentences where the details about the participants of the event and the identity of the event is predefined;

2 it is not a subcategorized argument of a verb and not a verb modifier;

3 its base verbs may belong to any of the Vendler aspectual classes, the thematic role of the verb's internal argument is not restricted;

4 it occurs only in colloquial speech.

The paper starts with a brief comparison with an earlier approach to the grammaticalization of Estonian aspect in verbal particles (section 2), followed by an introductory section on the data about the two uses of the particle (section 3). The rest of the paper presents the various differences between the particles in three parts: the aspectual nature of verb-particle combinations, including the interpretation of the result (section 4), combinability with verbs (section 5), syntactic differences (section 6). Section 7 presents the grounds for assuming the uses of the bounding particle as first signs on the way of a further stage in the grammaticalization of aspect in Estonian. Section $\mathbf{8}$ is the conclusion.

\section{Difference from earlier approaches}

Metslang (2001) describes the grammaticalization history of the particle ära 'away, up' as evolving from a directional adverbial ('away') to a

${ }^{1}$ I have reglossed the examples in order to unify glosses throughout the paper. The glosses will in some cases be omitted, for instance, when longer contexts are presented or the translation is unambiguous. The morphologically genitive or nominative (typologically or functionally rather to be seen as accusative, cf. Pusztay 1994, 48, Hiietam 2003) object case is referred to as the total object case, glossed according to the morphological form. The object bearing this case is referred to as the total object. 
purely perfective particle. The grammaticalization of the particle progresses through the three stages of directional and deictic meaning to directional deictic perfective meaning and to purely perfective meaning (Metslang 2001). Metslang writes that these three steps are present in Modern Estonian. First, the directional, deictic meaning, as in the example with the verb-particle combination ära saatma 'send, accompany away; see someone off' in example (2), quoted from Metslang.

(2) $\mathrm{Ta}$ saatis külalise ära.

he/she.(nom) accompany.(3sg.)past guest.gen ptcl

'He/she saw the guest off.'

(Metslang 2001, 445)

The second step and the second meaning are described as the perfective and deictic meaning in the sense of 'off, from the area of the deictic centre, to non-existence' (Metslang 2001, 445). This meaning is illustrated by the verb-particle combination ära tapma 'kill' and ära kaotama 'lose' as in the following example sentence (3), taken from Metslang (2001):

(3) Ta tappis külalise ära.

he/she.(nom) kill.(3sg).past guest.gen ptcl

'He/she killed the guest.

(Metslang 2001, 446)

The third meaning is called the pure perfective meaning and illustrated by an example with the verb 'give birth', illustrated here with Metslang's example in (4).

(4) (Kas te ootate ikka veel oma beebit? 'Are you still expecting your baby?' - )

Ei, eile sünnitas Mari ta lõpuks õnnelikult ära. no yesterday give_birth.(3sg).past Mari.(nom) he/she.gen at_last luckily ptcl 'No, luckily, yesterday at last Mari gave birth to it.' $\quad$ (Metslang 2001, 446)

Thus, schematically, Metslang's typology of the particle ära has the divisions as in Table 1.

Table 1

Metslang's stages of grammaticalization: the meanings of the particle $\ddot{a} r a$

\begin{tabular}{|c|c|c|}
\hline Stage 1 & Stage 2 & Stage 3 \\
\hline Directional deictic & Perfective+deictic & Purely perfective \\
\hline 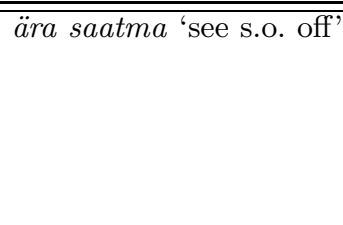 & $\begin{array}{l}\text { ära tapma 'kill', } \\
\text { ära kaotama 'lose' }\end{array}$ & 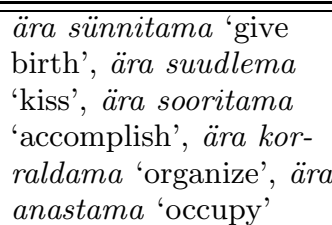 \\
\hline
\end{tabular}


I will demonstrate that the distinction between stage 2 and stage 3 particles can be drawn more clearly. Metslang's statement about the path of grammaticalization of the verbal particles is a good starting point to explain the principles for a clearer division of Estonian perfective verbal particles. Metslang writes about the path of grammaticalization that "[t]he Estonian verbal particles take a position along the path of directionals $\rightarrow$ completive $\rightarrow$ perfective" (Metslang 2001, 445). The division in the stage 3 data on particles reflects the fact that stage 3 particle uses may house both completive and non-completive uses, where completiveness is understood as the completion of the event with regard to encompassing ${ }^{2}$ an argument totally. Metslang's stage 2 particles are all completive. Therefore, one group of instances of stage 3 particles differs from another group of instances of the same stage 3 significantly more than from the instances of stage 2 particles. My point is that although Metslang defined the classes as being combinations of lexical items with the particle, some of her examples (the type 3 ones) are free, not argument structurally restricted combinations. I divide the perfective uses of the particle $\ddot{a} r a$ into two subuses: completive and bounding. These are referred to further as $\mathrm{CP}$, shorthand for completive particle, and $\mathrm{BP}$, shorthand for bounding particle. Table 2 below depicts my classification of Estonian perfective particles according to their aspectual nature and their relation to the arguments of the verb. This article does not discuss the various directional and completive particles in detail.

This division helps, on the one hand, to clearly distinguish uses that are close to what Metslang terms purely perfective from completive perfective uses. On the other hand, non-deictic and non-directional particleverb combinations such as (tuba) ära koristama 'tidy, clean (up) the room', which remain somewhat vaguely placed between pure perfective and directional deictic in Metslang's grammaticalization stages, are better integrated in the classification as the completive uses of the particle. There is no disappearance of the room in the course of the cleaning activity, but the particle denotes the completion of the room's changes of state from dirty to clean. On the other hand, this example differs from the ones associated by Metslang with the purely perfective meaning. The follow-

\footnotetext{
${ }^{2}$ Encompassing (this is a term that bears close resemblance to Kont (1963)'s term haarama 'grasp, encompass') is taken here as the total or complete traversal of the argument, as in read a book, creation or destruction of it, or a radical change of state of it.
} 
Table 2

The Estonian perfective particles

\begin{tabular}{|c|c|c|}
\hline $\begin{array}{l}\text { DIRECTIONAL } \\
\text { (ära, minema, tu- } \\
\text { lema 'away', etc.) }\end{array}$ & $\begin{array}{l}\text { COMPLETIVE } \\
\text { (ära 'completed', maha 'down', läbi } \\
\text { 'through', välja 'out', üles 'up', see } \\
\text { Hasselblatt (1990) for more examples) }\end{array}$ & BOUNDING (ära) \\
\hline $\begin{array}{l}\text { Denotes the com- } \\
\text { pletion of a path, } \\
\text { e.g., to 'away' }\end{array}$ & $\begin{array}{l}\text { Denotes the result or completion of } \\
\text { the activity or process encompassing } \\
\text { an argument }\end{array}$ & $\begin{array}{l}\text { Denotes the bounding of } \\
\text { an activity }\end{array}$ \\
\hline $\begin{array}{l}\text { ära saatma 'see } \\
\text { s.o. off', minema } \\
\text { minema 'go away', } \\
\text { tulema tulema } \\
\text { 'come away', välja } \\
\text { minema 'go out', } \\
\text { ära jooksma 'run } \\
\text { away' }\end{array}$ & $\begin{array}{l}\text { ära tapma 'kill', ära surema 'die', ära } \\
\text { kaduma 'disappear', ära kaotama } \\
\text { 'lose', läbi lugema 'read through', ära } \\
\text { korraldama 'organize, get done', ära } \\
\text { anastama 'occupy', maha müuma } \\
\text { 'sell out', maha rahunema 'calm } \\
\text { down', välja kannatama 'survive, to- } \\
\text { lerate', ära puhastama 'clean', valmis } \\
\text { küpsetama 'bake' }\end{array}$ & $\begin{array}{l}\ddot{a r a}+\text { mängima 'do, fin- } \\
\text { ish the playing', ära }+ \\
\text { jooksma 'do, finish the } \\
\text { running', ära + tegelema } \\
\text { 'do, finish the activity' } \\
\ddot{a r a}+\text { suudlema 'do, fin- } \\
\text { ish the kissing', ära }+ \\
\text { tutvuma 'do, finish the } \\
\text { getting acquainted with' }\end{array}$ \\
\hline
\end{tabular}

ing three paragraphs briefly compare the particle types in their relation to the arguments of the base verbs.

Directional ära denotes the completion of a path to "away". The closest Hungarian equivalent is the verbal prefix el- (elgurult a labda "the ball rolled away', eltette a könyvet 'he put the book away'). The closest English equivalent for this particle is away. Some examples follow: ära veere(ta)ma '(cause to) roll away', ära panema 'put away'. The terminus denoted by the particle pertains to the completion of the path to a terminus (endpoint or goal). The terminus is definable as a place different from the deictic centre. Verbs that combine with the directional ära have an implicit path argument that is not obligatorily realized as an overt syntactic argument. This article is not concerned with the directional and deictic meanings of the particle $\ddot{a} r a$.

Completive ära denotes the result or completion of the activity or process directed to a theme, experiencer or a patient argument (cf. the Hungarian types of arguments considered in É. Kiss 2004). The closest Hungarian equivalent is meg- (meghalt a hörcsög 'the hamster died', megolvasztotta a jeget 'he melted the ice'; el- for verbs of disappearance elhunyt 'passed away'). Examples are raiskas ära 'misspent', tappis ära 'killed', sulas ära 'melted'. Further examples of verbs that typically combine with CP are lugema 'read', sööma 'eat', surema 'die', and sulatama 'cause to melt', koristama 'clean (up) the room', and armuma 'fall in 
love'. The terminus denoted by the particle pertains to the completion of a change of state and the attainment of a result state. Typically, the terminus denoted by the particle pertains to the completion of an activity or a process that encompasses the whole extent of the theme, patient or experiencer argument referent. The result is definable as a state that is an opposite, or in any case a significantly different state from the previous state. Verbs that combine with the $\mathrm{CP}$ ära have a theme or patient argument that is obligatorily realized in overt syntax as an object or a subject. There are many subtypes of the $\mathrm{CP}$, and they will not be discussed in detail here.

Bounding $^{3} \ddot{a r a}$ denotes the achievement of the endpoint of an intended, planned, scheduled, or foreseen event. It occurs in transitive and intransitive sentences. Hungarian and English have no close equivalent, perhaps Hungarian meg- (megebédelt 'had his dinner', megfözök 'I'll do the cooking'; Kiefer 2000, 297), some Aktionsart-related uses of ki- (kialussza, kijátssza magát 'sleeps, plays his share, as much as needed', cf. Kiefer 2000, 292), or purely perfectivizing kitakarítok 'I'll do the cleaning' (Kiefer 2000, 297) resemble the Estonian bounding ära. The Hungarian túl-prefixation is close to the BP $\ddot{a r a}$ in its nature of being unrelated to the progress along the object argument, as in $X$ túlélte $Y$-t ' $\mathrm{X}$ lived longer than Y'. In English, out-prefixation is perhaps closest to the BP ära-prefixation. In an example like $X$ outate $Y$, the object argument is not related to the progress of the event - exactly as in the case of the BP ära. In its bounding nature and temporal independence of the event's evolvement and the verb's arguments, the particle also bears resemblance to the Russian perfective aspectual prefix po-. However, the bounding particle $\ddot{a} r a$ does not only indicate temporal boundedness; it also denotes the reaching of a distinct terminus, an endpoint. In this respect, the BP resembles more Hungarian le- or Russian pro- (as in ledolgozott három évet, on prorabotal tri goda 'he worked for three years, he spent three years working'). However, the endpoint in sentences with the BP is not necessarily related to the temporal measure argument, as the examples in the following sections will demonstrate. The BP $\ddot{a} r a$ is thus between

\footnotetext{
${ }^{3}$ Ackerman and Moore (2001) introduce a patient protorole that they term bounding. Their Estonian predicates containing ära have the "bounding" patient protorole entailment. My term bounding applies to a narrower set of uses of ära compared to what appears in their predicates with the bounding proto-role entailment in that I do not consider only resultative predicates. See this source and KieferHonti (2003) for more details about Estonian predicates and particles.
} 
po- and pro-, denoting the bounding of the event independenly of the arguments exactly as po-, but retaining the endpoint-oriented character of pro-. In its bounding meaning, the bounding particle resembles measure phrases. Some examples of sentences with the bounding particle are mängis ära 'did the intended, necessary playing, got done with the playing', suudles ära 'did the planned kissing, was done with the kissing'. Further examples of attested verbs that, perhaps less typically, can combine with the BP are jooksma 'run', tegelema 'be busy with', tutvuma '(make efforts to) get acquainted with', ehitama 'build', and küpsetama 'bake'. The verbs that combine with the BP ära typically have an agent argument that is either realized in overt syntax or not (e.g., in impersonal, imperative sentences).

In sum, the relevant distinction between these particle types as seen in this article is based on the lexical semantics of the base verbs, more specifically, on the involvement of the argument structure of the verbs in their combinations with these particles. The completive particle adds the meaning element of the completion of encompassing an argument (or its propety) to the full extent, as described by the verb. The bounding particle denotes the reaching of an independent planned, scheduled or intended endpoint of the activity, not necessarily related to the encompassing of an argument of the verb. The bounding particle occurs in sentences where the planning involves the event itself as described by the verb as well as the referents of the arguments of the verb. These differences suggest that the BP can be considered as a possible step further in the grammaticalization of Estonian perfectivity. The following subsection presents more data on the distinct uses.

\section{Introducing the data: bounding vs. completive particles}

\subsection{The completive particle}

In this subsection I will present some typical examples of one of the Estonian CP-s, the CP ära. Typically, consumption verbs such as sööma 'eat' as in (5) combine with the particle ära in its completive meaning type.

(5) Laps sõi kukli ära.

child.(nom) eat.3sg.past roll.gen ptcl

'The/a child ate the/a roll up.' 
As the result of the eating activity as described in sentence (5), the roll has necessarily disappeared, whatever the context.

(6) Päike sulatas jääpurika ära. sun melt.3sg.past icicle.gen ptcl 'The sun melted the/an icicle.'

As the result of the process evoked by the inanimate natural force causer as described in (6), the icicle has necessarily disappeared.

(7) Hamster suri ära. hamster die.3sg.past ptcl 'The hamster died.'

As the result of the events as described in (7) and (8), the hamster and the companion are dead.

(8) Ta tappis oma kaaslase ära. s/he kill.3sgpast own companion ptcl 'S/He killed his/her companion.'

Data on particle-verb combinations such as described here are to be found in many sources, such as the Grammar of the Estonian Standard Language (Erelt et al. 1993), Hasselblatt (1990), or Rätsep (1978). The typical, earlier relatively well-described particle uses are all completive uses of the particle (for the most extensive study, see Hasselblatt 1990). Metslang (2001) serves as a unique source since it contains a couple of cases recorded earlier of which I demonstrate that they cannot be analyzed as completive particle uses. Many examples in this paper are an elaboration of Metslang's examples.

\subsection{The bounding particle}

In this subsection I will introduce the BP $\ddot{a} r a$. The example sentences that I present about the bounding particle do not typically occur in written language. ${ }^{4}$ The following example of the BP, presented in (9), is a combination with the activity verb of manner of motion jooksma 'run'.

${ }^{4}$ The translations that I provide are not literal since there is no exact single literal translation that would convey the correct bounding meaning. Instead, I offer exact glosses but several free translations. As in (1), it is necessary for the purposes of illustration to provide examples of a possible (but note, not the only possible) context.

Acta Linguistica Hungarica 51, 2004 
(9) Iga päev käis Mari jooksmas, every day go.3sg.past M.(nom) run.mas-inf

pärast jooksmist läks bussiga ujuma.

after running.part go.3sg.past bus.comit swim.ma-inf

'Every day, Mari went running, after running she took the bus and went swimming.'

Täna juhtus aga nii.

today happen.3sg.past but so

'But what happened today was...'

Mari jooksis ära,

M.nom run.3sg.past ptcl

'Mari did the running...'

ent kuna millegipärast busse ei käinud,

but since for some reason bus.part.pl neg go.act.ptcpl

siis ei saanud ta ujuma minna.

then neg can.act.ptcpl s/he swim.ma-inf go.da-inf

'. . . but as the buses did not run/work for some reason, she could not go swimming.'

Here, the sentence (9) conveys that Mari spent (running) the span of time or distance she used to run every morning and then failed to start another intended activity that belongs to the conventional sequence of activities performed by her daily. This example resembles an example of Dowty $(1979,61)$, where John swam can have a telic interpretation in a context where John is known to swim a set distance every day - but it may be a set time as well. The next example (10) contains an intransitive activity verb tegelema 'be busy with something, deal with, be occupied with, work on something', a verb with no built-in endpoint or culmination.

(10) Kas lähme õue?

question particle go.1.pl out

'Shall we go out?'

Ei, vaata, laps tegeleb praegu nii kenasti voolimisega.

no look child.nom deal.3sg now so nicely modeling.comit

'No, look, the child is so well busy with modeling.'

Olgu, las ta siis tegeleb ära ja lähme siis.

ok let $\mathrm{s} /$ he then deal.3sg ptcl and go.1pl then

'That's fine, let's go then as soon as s/he's done with his/her modeling.'

The particle does not confirm or specify any natural endpoint as entailed or implicated by the verb's meaning. The meaning of the verb tegelema 'be busy with something, deal with, be occupied with, work on something' 
does not contain any natural endpoint. Without the contribution of the particle, the activity as described by this verb would be described as going on endlessly. The sentence in (10) conveys that the endpoint or boundary of the activity co-occurs with the moment when the child decides s/he's done with her modeling and at a certain moment, stops the activity. Compared to the example (9) with running, this example clearly indicates that the particle use is not dependent on a predefined set distance.

The next example (11) contains a verb with a built-in endpoint, tutvuma 'get acquainted with'.

(11) Mari tutvus materjaliga/(?)Katiga ära ja jalutas minema.

M.nom get-acquainted material/K.comit ptcl and walked away.

'Mari did the getting acquainted with the material/Kate and then walked away.'

This sentence describes that Mari had to or intended to be engaged in the activity of getting acquainted with the material or Kati and then walked away. ${ }^{5}$ The activity is more likely than not scheduled in between other activities or tasks and the use of ära can implicate that the "proper" result was not attained. The sentence can be also interpreted as having the result, the natural endpoint as described by the verb, where Mari is acquainted with Kati or the material.

Although the BP generally co-occurs with intransitive verbs, it is not impossible with transitive verbs either. Changing from intransitives to transitives, I will consider first simple activity verbs such as suudlema 'kiss', discussed in Metslang (2001). Activity verbs combine with the BP as illustrated in (12).

(12) Ta suudles tüdruku ära.

s/he kiss.3sg.past girl.gen ptcl

'S/he did the kissing of a girl.'

Metslang (2001) describes this sentence as having a context where one has made a bet to kiss the girl. The result, attaining what is required by the conditions of the bet, is introduced into the sentence by the particle.

The particle ära (as opposed to the lexically determined CP combinations valmis 'ready' or läbi 'through') is an instance of the bounding particle also when it appears with transitive, creation verbs such as

${ }^{5}$ The sentence with "material" is slightly more acceptable than that with "Kate". I am grateful to Ferenc Kiefer for pointing out the aspectually different nature of this verb with animate vs. inanimate complements cross-linguistically. 
küpsetama 'bake' (13), or with incremental theme verbs such as lugema 'read' (14). ${ }^{6}$

(13) Ta küpsetas koogi ära ja..

s/he bake.3sg.past cake.gen ptcl and

'S/He did the baking of the cake, s/he finished baking a cake and...'

In this sentence, the agent has previously decided to bake a cake, perhaps as a task. Having accomplished the cake baking, s/he goes on with another activity, task etc. Again, what is primarily described is not a resultant state of the cake. As the result of what is described in sentence (14), the agent is successfully over with the baking of the cake. This can be imagined as a part of a cooking-lesson at school, where a succession of tasks must be performed and marks are given. The following (14) presents a similar example, with the verb lugema 'read'.

(14) Ta luges raamatu ära ja..

he/she read.3sg.past book.gen ptcl and

"S/He did the reading of the book, s/he finished reading the book and...'

In this sentence, again, the agent has previously decided to read (some parts of) a given book, to do some reading of the book. As the result of what is described in sentence (14), s/he has read as much from the book as necessary, perhaps the whole book, or the necessary parts of it, or a certain necessary span of time is spent reading.

In sum, on the basis of the difference in the interpretation of the uses of the verbal particle $\ddot{a r a}$ there is evidence that the grammaticalization status of the verbal particle ära can be split into two types: the completive and bounding grammaticalization types. Further evidence is provided in three main parts: 1. Aspectual differences (section 4), 2. Lexical differences (section 5), 3. Syntactic differences (section 6).

\footnotetext{
${ }^{6}$ However, there is variation in judgments concerning the details about the verbs and contexts where the BP can occur. Even if many Estonian speakers intuitively feel that practically all or at least many verbs occur with ära, a more specific situation bounder is somehow "more correct" and the use of ära is "parasitic". Lexical restrictions and the typicality of situations are the two distinctions that may cause uncertainty in discussions of examples that follow here in (13)-(14). The data represented here is approved by and commented on by at least one additional native speaker.
} 


\section{The aspectual nature of verb-particle combinations}

\subsection{Aspect of base verbs, changes in aspectual class}

In this subsection I will discuss that the two different particle types tend to combine with different, but not mutually exclusive aspectual classes of verbs. While CP-s combine mainly with accomplishment and achievement verbs, there are examples of $\mathrm{BP}$ combinations with most verbs, activity verbs being the most typical ones to combine with BP-s. Table 3 presents examples of the particles' combinability with verbs.

Table 3

Particles and the Vendler classification

\begin{tabular}{|l|l|l|}
\hline Particle & CP + verb & BP+ verb \\
\hline \hline Achievement & $\begin{array}{l}\text { surema 'die', tapma 'kill', } \\
\text { hävitama 'destroy' }\end{array}$ & $\begin{array}{l}\text { tutvuma '(make efforts to) } \\
\text { get acquainted with' }\end{array}$ \\
\hline Accomplishment & $\begin{array}{l}\text { sööma 'eat', looma } \\
\text { 'create', sulama 'melt' }\end{array}$ & $\begin{array}{l}\text { ehitama 'build', } \\
\text { küpsetama 'bake' }\end{array}$ \\
\hline Activity/process & $\begin{array}{l}\text { koristama 'clean', lugema } \\
\text { 'read' }\end{array}$ & $\begin{array}{l}\text { mängima 'play', jooksma } \\
\text { 'run', tegelema 'be busy } \\
\text { with', suudlema 'kiss' }\end{array}$ \\
\hline State & - & olema 'be' \\
\hline
\end{tabular}

Verbs that combine with the CP are mainly predicates that have a possible built-in endpoint or culmination in their meaning, thus accomplishment (söoma 'eat') or achievement verbs (e.g., surema 'die'). The event that the verb denotes is such that it can encompass an argument completely. In contrast to the $\mathrm{CP}$, the $\mathrm{BP}$ primarily occurs with activity verbs such as mängima 'play', jooksma 'run', tegelema 'be busy with', suudlema 'kiss'. The BP occurs with accomplishment verbs, such as ehitama 'build', and küpsetama 'bake'. The BP is the only particle that occurs with some achievement verbs such as tutvuma '(make efforts to) get acquainted with'. Occasionally, the state verb olema 'be' in the sense of 'be somewhere' combines with the BP.

In conclusion, the two different particle types clearly combine with different, but not mutually exclusive aspectual classes of verbs. While $\mathrm{CP}-\mathrm{s}$ typically combine with accomplishment and achievement verbs, even if the most typical BP combinations are with activity verbs, there are examples of $\mathrm{BP}$ combinations with all aspectual classes of verbs. 


\subsection{The nature of the endpoints of the events}

This subsection articulates the difference between the endpoints of the events that are described. The $\mathrm{CP}$ describes a result that pertains to the completely encompassed state of an argument; the endpoint of the event denoted by the BP pertains to the achievement of an expected or scheduled change in a situation. The endpoint that is denoted by the BP may, but need not, coincide with any result that involves the argument.

\subsubsection{CP results}

The CP $\ddot{a r a}$ denotes an endpoint that is a result state of the complete encompassing of the theme, patient, or experiencer argument. As the result of the activity that is described by the verb and described to be fully completed by the $\mathrm{CP}$, the participants of the event are changed, created, traversed or destroyed totally. The resultant state of the roll from sentence (5) with the verb eat and that of the icicle from sentence (6) with the verb melt is that they have disappeared. The resultant state of the hamster from sentence (7) with the verb die, or the companion from sentence (8) with the verb kill is that they do not exist any more. In a way, the participants of the described events are ära 'away' in Metslang (2001)'s sense of fully not being in the area of the deictic center, being off or away. There are more examples where ära only adds the completive meaning. For instance, the room is not ära 'away', but ära koristatud 'cleaned up, tidy' as the result described by CP-verb combinations such as in sentence (15) with the verb koristama 'tidy'.

(15) Mari koristas toa ära.

M.nom clean.3sg.past room.gen ptcl

'Mari cleaned the room.'

The patient participant of the event is changed totally in one of its qualities.

\subsubsection{BP endpoints}

In contrast to $\mathrm{CP}$ results, the $\mathrm{BP}$ denotes the achievement of an expected or scheduled change in a situation through reaching a boundary or endpoint. Similarly to typical CP results, the state of the argument kloun 'clown' described in (1), with the verb mängima 'play', cannot be described with what is the lexical content of ära. But differently from the CP combinations, sometimes the change of state does not even involve the argument since the clown is non-referential in (1). There is no 
necessary change involved in the referential arguments, such as in the sentence (12) (with suudlema 'kiss'), either. However, the claim that there is no change that involves an argument is somewhat more difficult to support in the case of verb-BP combinations where the meaning of the base verb contains already a built-in endpoint and the arguments do undergo a change. For instance, the activities of baking the cake (13) or reading the book (14) can be understood as finished and completed. But crucially, what is described in the BP sentences (1), (9)-(14) is not a complete change in the argument referent. Exactly this argument-relatedness is the key to the relevant difference between $\mathrm{BP}$ results and $\mathrm{CP}$ results. Let us compare the verb lugema 'read' in combination with the CP läbi (15) (see more on different CP-s in section 5.3) and the BP ära (16) in the following two sentences:

(16) $\mathrm{Ta}$ on raamatu läbi lugenud...

he/she be.3sg.past book.gen ptcl/through read.act.ptcpl

'S/he has read a/the book through...'

\#... pool sellest loetud raamatust jäi lugemata,

half of this read book left unread

selle peab ta homme lugema.

this.gen must he tomorrow read.ma-inf

'... half of the read book remained unread, this s/he is going to read tomorrow.'

What is described in (16) entails that the whole book is read through. The following sentence (17) entails that some reading is done, but the result of a book being read through is not an entailment but an implicature as evidenced by the cancellation.

(17) Ta on tänaseks oma raamatu ära lugenud...

s/he be.3sg.past today.transl his/her book.gen ptcl read.act.ptcpl

'S/he has done her reading of the book (book-reading) for today...'

?... pool sellest loetud raamatust jäi lugemata,

half of this read book left unread,

selle peab ta homme lugema.

this.gen must he tomorrow read.ma-inf

'... half of the read book remained unread, this s/he is going to read tomorrow.'

The outcome in (17) is that as for the book, the reading of it has been accomplished to some extent at least. As for the intended goal of the activity, what is described in (17) entails that this goal is fully reached by doing the reading exactly to the extent it was done. 


\section{Lexical differences among the base verbs}

This section presents further evidence that $\mathrm{BP}$ and $\mathrm{CP}$ must be considered as separate phenomena. First, the lexical semantic characteristics of the base verbs that the $\mathrm{BP}$ and $\mathrm{CP}$ combine with are different, and the way the lexical semantics of the base verbs interacts with the meaning of the particles is also different. Second, while the BP combines more freely and the combinations are always transparent, the different CP-s combine with verbs according to the verbs' lexical semantic class. Also, only CP-s occur in opaque verb-particle compositions.

\subsection{Selection criteria of the particle for the thematic roles involved}

This section demonstrates that the occurrence of the bounding particle is not restricted according to the thematic roles of the base verb. The occurrence of the completive particle is restricted to verbs with a theme, a patient, or an experiencer argument.

\subsubsection{The CP}

The CP combines only with verbs that have an internal argument. The verbs that combine with the $\mathrm{CP}$ have typically either a theme or a patient argument (surema 'die', sööma 'eat', tapma 'kill', sulatama 'melt'). These are the thematic roles that are relevant for expressing aspectual oppositions that are frequently referred to as phenomena of telicity, or delimitedness (cf. Krifka 1992, Tenny 1994). These CP-verb combinations that have theme, patient, or experiencer arguments typically denote the following types of changes:

(a) a change of state (ära koristama 'clean', ära hellitama 'spoil by pampering', ära jahtuma 'cool down', ära hirmutama 'scare s.o. to death', ära harjuma 'get accustomed', ära rikkuma 'spoil, ruin', ära ummistuma 'get stuck', ära seedima 'digest', ära vaevama 'tire, vex', ära venitama 'ruin by stretching', ära hõorduma 'get scratched, suffer friction'), typically denoting gradual progress through a succession of changes of states, also mental; frequently in the sense of deterioration or harm;

(b) traversal, change of state via incremental progress through or over the extent of the theme argument (läbi lugema 'read through', ära söoma 'eat up', ära õgima 'devour', ära tallama 'trample down', ära ôppima 'learn', läbi kuulama 'listen to all of it', valmis kirjutama 'write up', üles tähendama 'write down', läbi mängima 'play through', ette kandma 'perform', ära jaotama 'divide', ära seletama 'explain'). 
(c) complete mental encompassing of an incremental theme by the senses, ära kuulma 'hear all of it, have it heard', ära nägema, kaema 'see all of it, have it seen', ära proovima 'give it a try', ära katsuma 'touch', ära kannatama 'survive or tolerate the whole extent of it'.

(d) creation and destruction, coming into existence and ceasing: ära tapma 'kill', valmis küpsetama 'bake ready', valmis ehitama 'build so that it is ready', ära tarvitama 'use up', ära hävitama 'destroy'.

The completive particle denotes the completion of the change or the progress through (a property of) the theme, patient, or experiencer argument. The complete change of the argument referent (koristama 'clean'), or the complete traversal of it (lugema 'read') determines the endpoint of the event. The external argument of these verbs can have the agent thematic role as in the case of sö̈ma 'eat', tapma 'kill', but this is not a necessary condition, e.g., sulatama 'melt', armuma 'fall in love', or surema 'die'.

\subsubsection{The BP}

In contrast to the $\mathrm{CP}$, the occurrence of the $\mathrm{BP}$ is not dependent on the thematic nature of the internal arguments of the verb, and the verbs combining with it are primarily intransitive-agentive or transitive. The thematic role of the internal argument of the verb, direct or indirect, displays a variety of possibilities: instrument (mängima 'play', tegelema 'be busy with'), theme, and patient (suudlema 'kiss', and küpsetama 'bake'). The presence of a direct internal argument is not a necessary condition for BP-verb combinations: in case of mängima 'play', the argument is optional, in case of tegelema 'be busy with', there is none. Section $\mathbf{6 . 2}$ below presents the data about the omitted objects. Whether the meaning of the verb with its arguments entails a change and whether the progress of the event needs to involve incremental traversal through the (properties of) arguments is irrelevant in case of combinations with the BP (see the description of the data in 3.2 and 4.2.2). The BP occurs with verbs the external argument of which is an agent. The requirements that emerge for combining with the BP are strikingly similar to the conditions of the durative (progressive) interpretability of Estonian achievement and accomplishment verbs. Kiefer $(1992,100)$, commenting on the conditions of the formation of the Hungarian progressive with prefixed/perfective-durative verbs, notes that the condition that the agent must act intentionally is not part of grammar but is rather a cognitive principle based on everyday knowledge. This principle can be assumed to work here. The BP 
occurs if the described event is carried out according to a plan or expectation, planning and expectations in turn require that there be a planner or evaluator. This cannot be non-human or at least not inanimate.

\subsubsection{BP and CP compared}

In sum, the occurrence of the $\mathrm{CP}$ is dependent on the nature of the direct internal argument's thematic role. Differently from the $\mathrm{CP}$, the $\mathrm{BP}$ is more felicitous (but not restricted to) with verbs the subject of which has the agent thematic role, whereas the object's thematic role does not constrain the verb's combinability with the BP. The BP does not complete any activity related to an argument but denotes the completion of an event according to a plan or expectation. For felicity reasons, there must be a planner.

\subsection{Transparency of meaning of the combinations}

While opaque verb-particle combinations are abundant with the $\mathrm{CP}$, there are no clear instances of BP-s in opaque verb-particle combinations. Both perfective particles can form transparent, compositional particleverb combinations. Occasionally, a CP-verb complex has a partitive object, since the whole opaque lexical complex denotes a state or an activity and the completive-resultative meaning component is missing, e.g., ära kasutama 'take advantage of, use in one's own interests, use for one's own purposes' or üles näitama 'show, expose' have a partitive object in sentences. Normally, however, the opaque CP-verb combinations have total objects, as in jagama 'divide' - ära jagama 'grasp, understand', virutama 'hit' - ära virutama 'steal', intransitive examples: viskama 'throw' - ära (üle) viskama 'make s.o. feel fed up with sth', pöörama 'turn' - ära pöörama 'become mad, crazy'. For further opaque examples I refer the reader to Metslang (2001). Hasselblatt (1990)'s examples that are provided with the label ID, that is, idiomatic, are a further extensive source for opaque verb-CP combinations. The facts about the idiomatic combinations demonstrate that the $\mathrm{CP}$ is more tightly connected to the base verb.

\subsection{Other perfective $\mathrm{CP}$-s}

$\ddot{A r a}$ is the only particle with the characteristics of a BP in Estonian. In contrast, there are several means to express the completive endpoint 
or result. Completion can be expressed by what are called in the Estonian tradition 'perfective or perfectivizing adverbs' such as valmis 'ready, completed', resultative phrases (translative-marked phrases) and several other particles that are referred to as perfective particles next to ära 'up, away, done', for instance, läbi 'up, through', maha 'down', üles 'up' (for a more exhaustive list, see Hasselblatt 1990). On the basis of many earlier sources it can be confirmed that these particles form opaque compositions with the verb.

\subsection{Summary}

In sum, next to the perfective particle $\ddot{a} r a$, which emerges as two types, there are other perfective particles in Estonian. Other perfective particles display similarities with the completive perfective type only. The CP combinations are mainly transparent. Opaque combinations are attested only with the $\mathrm{CP}$. This section provides more evidence that $\mathrm{BP}$ and $\mathrm{CP}$ must be considered instances of separate particle uses.

\section{Syntactic differences}

The data from section 5 suggest that the nature of combining the two types of particles with the verbs is different. Syntactically, however, neither of the particles emerges as a bound morpheme; they are both separable. This section presents evidence about those differences between $\mathrm{CP}$ and $\mathrm{BP}$ that appear in syntax. The discussion starts with pointing at the relevant similarities and then turns to the differences in word order, omission of objects and of particles, and derivation.

\subsection{Similarities}

The perfective particle $\ddot{a} r a$ is typically stressed, and typically occupies a clause-final position (see (1)-(14)). Generally it does not precede the finite verb. ${ }^{7}$ This generalization has some exceptions. In subordinate clauses and in other typically verb-final sentences such as interrogative

${ }^{7}$ Cf. the criteria mentioned in Kiefer-Honti (2003) and see that source for more Estonian data. In the corresponding negative sentences, the negation clitic ei precedes the verb in its active participial form.

Acta Linguistica Hungarica 51, 2004 
sentences (see Erelt 2003, 100 for these environments), and in case of neutral word order, the particle precedes the finite verb (18).

(18) Ma ei tea, kas ta õuna ära sõi.

I neg know if $\mathrm{s} /$ he apple.gen ptcl eat.3sg.past

'I do not know if he ate up the apple.'

The same distribution is also characteristic of the BP, as seen from (19):

(19) Ma ei tea, kas ta klouni ära mängis.

I neg know if $\mathrm{s} /$ he clown.gen ptcl play.3sg.past

'I do not know if did play the clown.'

With these data, there is no evidence of a different distributional status of these two particles in terms of occurrence in front of a finite verb. The following data concern the differences.

\subsection{The omission of objects}

The omission of the object reveals a difference in well-formedness of the sentences between the $\mathrm{CP}$ and the BP. The object cannot be dropped in verb-CP combinations. The omission of the object results in ungrammatical sentences as in (20), (21):

(20) Päike sulatas jääpurika ära.

sun.nom melt.3sg.past icicle.gen ptcl

'The sun melted the/an icicle.'

(21) *Päike sulatas ära.

sun.nom melt.3sg.past ptcl

The CP requires the presence of an object. The verb-BP combination always co-occurs with total objects if there is an object as in sentence (1). In contrast to CP-s, it is possible to omit the object from sentences with the BP. In many cases, what seems to be a difference between two particles may be simply a reflection of the opposition between an obligatory and optional argument. Therefore, it is necessary to study the combination of the $\mathrm{BP}$ with a predicate with an obligatory argument in sentence (21), which contains the verb suudlema 'kiss'.

\footnotetext{
${ }^{8}$ See the sentence (12) from section $\mathbf{3 . 2}$ for the description of a felicitous context.
} 
(22) Ta suudles (tüdruku) ära.

s/he kiss.3sg.past girl.gen ptcl

'S/he did the kissing (of a girl).'

The combination of the $\mathrm{BP}$ with a predicate with an obligatory argument allows omitting the object. There can be many accounts of this behavior, and some of the options may give a solution in a combined form. First option: the reason can be information structural. Discourse-old material is more likely to be omissible in many languages, and the theme argument here represents information that was introduced earlier. However, subsection 6.4 presents evidence that the typical referents of the objects in sentences with the CP are also discourse-old. Second option: certain thematic roles tolerate the omission of the material that carries those roles; patients are typically not omissible. However, there is (at least intuitively) no difference between the roles of the phrase 'girl' in a sentence with and without the particle in (22). In both cases, the phrase 'girl' represents a theme argument. Third option: the reason can be also that the theme argument is a kind of verb modifier in (22) - thus, not obligatory. In this case, it is not the particle that is the verb modifier, but the noun phrase 'girl'; the particle is a VP-modifier. Fourth option: the CPverb combinations specify a measuring scale for an event lexically. That is, these combinations specify a participant in the event that provides a "single gradable parameter or scale along which the event transpires over time, and the endpoint of the scale" (Tenny 1994, 94). An example is the case with 'melt (up)', where the disappearance of the icicle corresponds to the transpiration of the event. Whether the physical extent of the participant (the icicle) itself provides this scale - as Tenny suggests - or a property of this participant (the volume of the icicle), as suggested by Hay et al. (1999), would take us beyond the scope of this study. However, it is important to note that the argument that stands for the participant that is related to the evolvement of the event in a particular way is not omissible. In contrast, the arguments that stand for participants that are not related to the evolvement of the event can be omitted. These speculations aside, tolerating the omission of the obligatory argument object reveals a clear difference between the verbal particles.

\subsection{Omission of particles}

This subsection will demonstrate that the two particles behave differently with regard to tolerating their omission from the sentence: the omission 
of a CP still yields grammatical sentences with the total object even if the sentence becomes context-dependent; the omission of the BP can yield ungrammatical sentences with the total object, depending on the base verb class. In the case of many verbs without a built-in endpoint, such as the previously discussed suudlema 'kiss' in (22), the omission of the particle would lead to ungrammatical sentences (23) with the total object case, the object case must be partitive with this verb.

(23) *Ta suudles tüdruku. s/he kiss.3sg.past girl.gen

Intended meaning: 'She did the kissing of a girl.'

Ungrammaticality arises because the verbs that can combine with the BP and not with the CP lexically often do not contain any built-in endpoint; in the event in (23), the argument is not encompassed completely. If the event that the verb denotes is such that it can encompass an argument completely, the particle can be omitted as in (24). As discussed in section 4.1, the CP typically combines with such verbs.

(24) Igaüks pidi kolm raamatut läbi lugema.

everybody.(nom) must.3sg.past three.nom book.part through read.ma-inf 'Everyone had to read through three books.'

Kadri luges kaks raamatut Aasia kohta ja ühe K.(nom) read.3sg.past two.nom book.part Asia.gen about and one.gen raamatu Aafrikast.

book.gen A.ela.

'Kadri read two books about Asia and one book about Africa.'

The omission of the particles is possible with no effect on object case if there is an incremental theme base verb and the combination is transparent. However, it must be pointed out that the information structural properties of the sentences are different. As for opaque combinations, they do not tolerate the omission of particles for reasons of loss of the lexical meaning. In sum, the omission of a $\mathrm{CP}$ can yield grammatical sentences with the total object even if the sentence becomes contextdependent; the omission of the $\mathrm{BP}$, depending on the base verb class, can yield ungrammatical sentences with the total object. The contrast between (22) and (23) indicates that the object case in combination with the BP is changed. 


\subsection{The participation of the particle in the information structure of the sentence}

As described in Metslang (2001) and Rajandi-Metslang (1979), the position of the objects or obliques with regard to the CP reflects the organisation of the information structure as in (25), (26); the BP, being the only rhematic element in the sentence, has a fixed position and relates to only one information structural option. In sentence (25), where the particle in the stressed sentence-final position follows the unstressed total case marked object NP, the object represents known or old information. Metslang describes the aspect in this case as perfective.

(25) Mari koristas toa ära

M.(nom) clean.3sg.past room.gen ptcl

'Mari cleaned the room.'

In (26), the stressed particle precedes the total case marked object NP, and this sentence type is described as perfective, thus, the difference in word order does not result in any change in object case or aspect. The object conveys here introduced or new information according to Metslang, this information may be considered more specifically, contrasted in (26), that is, there is a choice between things to clean (up) and what Mary cleaned is a room.

(26) Mari koristas ära toa.

M.(nom) clean.3sg.past ptcl room.gen

'Mari cleaned a/the room.'

In contrast, the $\mathrm{BP}$ does not function as an information structurer, that is, the object in the sentence cannot be contrasted. In the intransitive sentence (27), playing with cars belongs to the known, old information as something scheduled, planned and foreseen.

(27) Mari mängis autodega ära.

M.(nom) play.3sg.past car.pl.comit ptcl

'Mari finished playing with the cars.'

In (28), the placement of 'the cars' in the position after the particle as new information yields a strange effect, since this verb can combine only with a BP and describe a scheduled, planned or foreseen event as involving the verb and the referents of its arguments. 
(28) ?Mari mängis ära autodega.

M.(nom) play.3sg.past ptcl car.pl.comit

'Mari finished playing with cars.'

And again, in a transitive sentence (29), clown-playing belongs to the earlier discourse as a part of the scheduled sequence of events.

(29) Mari mängis klouni ära.

M.(nom) play.3sg.past clown.gen ptcl

'Mari finished playing the clown.'

In (30), the total case marked 'clown' appearing in the position associated with new information yields a strange effect.

(30) ?Mari mängis ära klouni.

M.(nom) play.3sg.past ptcl clown.gen

'Mari finished playing a clown.'

There are many ways of understanding these data. One property of the $\mathrm{CP}$ is participation in organizing the information structure of the sentence. On the other hand, the BP does not display this ability since one cannot introduce the referents of the verb's arguments in a sentence with the BP. It is also possible that the case-marked 'clown' (29), (30) and 'cars' (27), (28) are verb modifiers, whereas 'room' is an object in (25), (26), as suggested in subsection $\mathbf{6 . 2}$ above. In that case, it is plausible that a verb modifier is positioned closer to the verb; the particle $\ddot{a} r a$ is in the last positioning the sentence. However, then it is difficult to understand the data in (18) and (19), which indicate that there is no distributional difference between the two particles in at least in some environments. In conclusion, the two particles have different distributional properties in some environments. The following section provides evidence that they enter morphological derivation differently.

\subsection{No deverbal adjective formation with the BP}

Deverbal participial adjective formation suggests that the two uses of the particles are also syntactically different. Deverbal (participial) adjective formation is only acceptable with CP-s. The combinations of particles and verbs, including $\ddot{a} r a$-verb combinations, behave differently in adjectival participle formation as illustrated in the following exampels. While it is possible to have sentences containing deverbal adjectives with 
the $\mathrm{CP}$ as witnessed by (32), the combination is anomalous with the BP as evident from (31). ${ }^{9}$
(31) \#Ta pani ära küpsetatud koogi lauale.
s/he.(nom) put.3sg.past BP bake.pass.ptcpl cake.gen table.all
'S/he put the baked cake on the table.'

(32) with a CP serves to demonstrate that the particle ära as a form is an acceptable element in the deverbal adjective formation; therefore, there is again evidence for the distinction between $\mathrm{CP}$ and $\mathrm{BP}$ uses of the particle $\ddot{a r a}$.
(32) Ta pani ära lõhutud vaasi lauale.
s/he.(nom) put.3sg.past CP break.pass.ptcpl vase.gen table.all
'S/he put the broken vase on the table.'

There are several ways to understand the difference in the data about why a cake cannot be ära küpsetatud $;^{10}$ it must be valmis küpsetatud 'baked ready'. These data may also indicate that these two particle types may have different structural characteristics; here follows a possible explanation. The BP does not combine with adjectives and nouns - but the CP doesn't either. In particle-participle combinations, thus, neither of these particles combines with an adjective. The difference is in the input of the derivation process. The $\mathrm{CP}$ as part of the verb enters the verb-based derivation and as a consequence, the $\mathrm{CP}$ that appears in the derivation does not modify the adjective and the formation is acceptable. The BP, being not a part of the verb, does not enter the morphological

${ }^{9}$ This sentence, however, definitely needs embedding in the background context:

Kuidas tal lood selle koogiga on? Kas ta sai küpsetamisega hakkama?

'How are things with this cake? Did she manage the baking?/Did she manage to bake it?-

Jah, pärast pikka vaevanägemist küpsetas ta (selle) lõpuks siiski edukalt ära ja sai oma viie kätte.

'Yes, after a long struggle she did the baking of it successfully still and got her good mark.'

In the representation of particles and deverbal adjectives, there is also a normative issue of writing the particle separately or attaching it to the deverbal adjective, not discussed here. See Tauli $(1972,127-8)$ for further details.

${ }^{10}$ It is possible to interpret the combination if baking is understood to affect a cake so that its crust becomes burned or too crispy, or if ära pertains to changing the relevant extent of it. Evoking those interpretations, however, requires extra processing as opposed to valmis. 
verb-argument based derivation and as a consequence, in BP-participle combinations, the $\mathrm{BP}$ is left to modify an adjective. The outcome is not grammatical - the BP, as any other particle, cannot modify an adjective. Table 4 presents the difference in the derivations.

Table 4

Deverbal adjectives and the $\mathrm{CP} / \mathrm{BP}$ distinction

\begin{tabular}{|c|c|}
\hline $\mathrm{CP}$ & BP \\
\hline $\begin{array}{l}\text { ära sulatatud jä̈̈purikas 'the icicle } \\
\text { that has melted' } \\
\text { valmis küpsetatud kook 'the cake that } \\
\text { has been baked (ready)' }\end{array}$ & $\begin{array}{l}\text { \#ära küpsetatud kook (baked cake) } \\
\text { \#ära suudeldud tüdruk (kissed girl) } \\
\text { \#ära mängitud kloun (played clown) }\end{array}$ \\
\hline
\end{tabular}

In sum, the issue of deverbal (participial) adjective formation calls for further research. It is an area where the two particles display a significant difference. On the basis of the information, the BP ära, in contrast to the CP-s, cannot be incorporated together with the verb in the course of this operation.

\subsection{Summary}

Many syntax-related differences indicate that there are uses of Estonian verbal particles that differ considerably. The BP and the CP are separable verbal particles that combine with verbs transparently, but the opacity of many CP-verb combinations (see section 5.2) may suggest that the $\mathrm{CP}$ is syntactically more closely related to the verb than the BP is.

\section{Reasons for not considering the BP as completely grammaticalized}

This section points out some reasons why, despite its distinct characteristics, the bounding perfective particle cannot be considered as firmly established in its function as an aspectual marker. The BP occurs only in spoken language. There is variation in judgments about the details concerning the verbs and contexts where the BP can occur. In borderline cases (verbs with an agent and a patient or theme, e.g., verbs of creation) there is uncertainty about the type of the perfective particle. 


\section{Conclusion}

This article presented two grammaticalization types of separable perfective particles in Estonian. The bounding particle (BP) use of the semantically bleached separable verbal particle ära was demonstrated to display a distinct status in the grammaticalization of aspect. The special character of the BP was illustrated by contrasting the BP ära, on the one hand, with the well-established use of the particle with the same form (ära) and, on the other hand, with several other perfective particles, which are referred to here as instances of completive particles (CP). The study of differences brought out several novel facts about the BP. The particle occurs only in context-dependent, agentive sentences that typically describe the achievement of planned or foreseen endpoints of events. Perfective sentences with the BP contain primarily activity verbs; however, verbs in such sentences can belong to any of the aspectual classes, and the combinations are transparent. The occurrence of an argument that would serve as a "measure" for the event is thereby optional. The evidence that the $\mathrm{BP}$-verb combinations do not allow for the derivation of adjectives (passive participles) also demonstrates the difference between the principles of combining a verb and a $\mathrm{BP}$ as opposed to a $\mathrm{CP}$. The bounding perfective particle $\ddot{a} r a$ cannot be considered fully grammaticalized and established in its function as an aspectual marker, but it has developed its distinct semantic and syntactic character as opposed to the CP-s.

\section{References}

Ackerman, Farrell - John Moore 2001. Proto-properties and grammatical encoding: a correspondence theory of argument selection. CSLI Publications, Stanford University.

Dowty, David 1979. Word meaning in Montague Grammar. Dordrecht, Reidel.

É. Kiss, Katalin 2004. Egy igekötőelmélet vázlata [Outlines of a theory of the verbal particle]. In: Magyar Nyelv $100: 15-43$.

Erelt, Mati 2003. Estonian language (Linguistica Uralica. Supplementary Series. Vol.1.). Eesti Teaduste Akadeemia Keele ja Kirjanduse Instituut, Tallinn.

Erelt, Mati - Reet Kasik - Helle Metslang - Henno Rajandi - Kristiina Ross - Henn Saari-Kaja Tael-Silvi Vare 1993. Eesti Keele Grammatika II. Süntaks. Lisa: Kiri [The grammar of the Estonian language II. Syntax]. Eesti Teaduste Akadeemia Keele ja Kirjanduse Instituut, Tallinn.

Hasselblatt, Cornelius 1990. Das Estnische Partikelverb als Lehnübersetzung aus dem Deutschen. Veröffentlichungen der Societas Uralo-Altaica, Wiesbaden. 
Hay, Jennifer-Christopher Kennedy-Beth Levin 1999. Scalar structure underlies telicity in "Degree Achievements". In: T. Mathews-D. Strolovitch (eds): SALT IX, 127-44. CLC Publications, Ithaca.

Hiietam, Katrin 2003. Definiteness and grammatical relations in Estonian. Doctoral dissertation, University of Manchester, Manchester.

Kiefer, Ferenc 1992. Aspect and conceptual structure: the progressive and the perfective in Hungarian. In: Ilse Zimmermann-Anatoli Strigin (eds): Fügungspotenzen, 89-110. Akademie-Verlag, Berlin.

Kiefer, Ferenc 2000. Jelentéselmélet [Semantic theory]. Corvina, Budapest.

Kiefer, Ferenc-László Honti 2003. Verbal "prefixation" in the Uralic languages. In: Acta Linguistica Hungarica $50: 137-53$.

Kont, Karl 1963. Käändsõnaline objekt läänemeresoome keeltes [The declined object in Baltic Finnic languages]. ENSV Teaduste Akadeemia Keele ja Kirjanduse Instituudi uurimused IX, Tallinn.

Krifka, Manfred 1992. Thematic relations as links between nominal reference and temporal constitution. In: Ivan Sag-Anna Szabolcsi (eds): Lexical Matters, 29-53. CSLI Publications, Stanford.

Metslang, Helle 2001. On the developments of the Estonian aspect: the verbal particle ära. In: Östen Dahl-Maria Koptjevskaja-Tamm (eds): The Circum-Baltic languages: their typology and contacts (Studies in Language Companion Series 55), 443-79. John Benjamins, Amsterdam \& Philadelphia.

Pusztay, János 1994. Könyv az észt nyelvről [A book on Estonian] (Folia Estonica. Tomus III). Savariae, Szombathely.

Rajandi, Henno-Helle Metslang 1979. Määramata ja määratud objekt [The nondefined and defined object]. ENSV Teaduste Akadeemia Keele ja Kirjanduse Instituut, Valgus, Tallinn.

Rätsep, Huno 1978. Eesti keele lihtlausete tüübid [Types of Estonian simple sentences] (ENSV TA Emakeele Seltsi toimetised 12). Valgus, Tallinn.

Tauli, Valter 1972. Eesti grammatika I. Hääliku-, vormi- ja sõnaõpetus [Estonian grammar. Phonology, morphology, and lexicology]. Institutionen för finsk-ugriska språk, Uppsala.

Tenny, Carol 1994. Aspectual roles and the syntax-semantics interface (Studies in Linguistics and Philosophy 52). Kluwer Academic Publishers, Dordrecht.

Address of the author: Anne Tamm

Research Institute for Linguistics

Hungarian Academy of Sciences

Benczúr utca 33.

H-1068 Budapest

anne_tamm@yahoo.com 